\title{
PERLINDUNGAN HUKUM TERHADAP ANDALIMAN (MERICA BATAK) SEBAGAI INDIKASI GEOGRAFIS DI KABUPATEN TOBA SAMOSIR
}

\author{
Mareci Susi Afrisca Sembiring \\ Magister Ilmu Hukum, Universitas Atma Jaya Yogyakarta \\ Jalan Babarsari 43 Sleman, 55281 \\ marecisembiring@gmail.com
}

\begin{abstract}
The objective of this study is to explain Andaliman product fulfill the elements basis as the geographical indication of Toba Samosir Regency, and to know the efforts of the government of Toba Samosir Regency to protect that. This research is a empirical research with the primary data collected, combining with the secondary data of law. The result shows that Andaliman product has fulfill elements as the geographical indication of Toba Samosir regency. It has a strong management product, Second; the prime and consistent product; the strong promote of product; the huge and sustainable product; In other hand it has not been registered yet by The goverment of Toba Samosir Regency, since they didn't know yet about the geographical indication provision. In fact, this registration is needed to provide stronger legal protection.
\end{abstract}

Keywords: Andaliman(Batak Pepper), Geographical Indicaton, Legal Protection.

\begin{abstract}
Abstrak
Penelitian ini bertujuan untuk menjelaskan apakah produk Andaliman memenuhi elemen sebagai indikasi geografis Kabupaten Toba Samosir serta menjelaskan upaya yang dilakukan oleh Pemerintah Kabupaten Toba Samosir untuk melindungi Andaliman sebagai indikasi geografis. Untuk memperoleh data dilakukan penelitian empiris yang didukung dengan penelitian kepustakaan. Hasil penelitian ini menunjukkan bahwa Andaliman memenuhi unsur-unsur indikasi geografis, antara lain: memiliki sistem manajemen yang kuat dan efektif; kualitas produk yang prima dan konsisten; sistem pemasaran dan promosi yang kuat; mampu memasok kebutuhan pasar dalam jumlah cukup dan berkelanjutan. Di sisi lain Pemerintah Kabupaten Toba Samosir belum melakukan pendaftaran untuk Andaliman sebagai indikasi geografis untuk Kabupaten Toba Samosir, karena belum memahami peraturannya. Padahal, pendaftaran ini dibutuhkan untuk memberikan perlindungan hukum yang lebih kuat.
\end{abstract}

Kata Kunci: Andaliman (Merica Batak), Indikasi Geografis, Perlindungan Hukum.

\section{A. Pendahuluan}

1. Latar Belakang Permasalahan

Indonesia merupakan negara yang dikenal memiliki keanekaragaman hayati yang tinggi. Di samping memiliki keanekaragaman hayati yang tinggi, Indonesia juga mempunyai beragam budaya dan karya tradisional. Tanpa disadari banyak aset dan kekayaan intelektual lokal itu telah terdaftar di luar negeri ataupun di negara lain sebagai milik orang asing. Kurangnya kesadaran akan pentingnya aset karya intelektual ini telah mengakibatkan kerugian yang besar bagi Indonesia (Adrian Sutedi, 2009:6). Indonesia merupakan negara yang kaya akan produk potensi Indikasi Geografis, sebagai salah satu contoh yaitu Andaliman si Merica Batak. Potensi alam ini sesungguhnya menjadi anugerah bagi bangsa Indonesia khususnya daerah Toba Samosir untuk pertumbuhan ekonomi, jikalau potensi tersebut dapat dimanfaatkan dan digunakan sebagai aset perdagangan. Dalam konteks ini, apabila potensi tersebut masuk ke dalam kategori aset bisnis atau perdagangan, maka aturan hukum harus dapat menjamin agar 
hak-hak pihak yang memanfaatkan potensi tersebut dapat terlindungi. Apalagi jika potensi tersebut sudah diperdagangkan ke dunia internasional (export dan import).

Salah satu peran dari hukum adalah untuk memberikan perlindungan. Prinsip hukum itu pasti harus dilaksanakan serta ditegakkan, bagaimana hukumnya itulah yang harus berlaku dan harus dijalankan. Sudah sangat mendasar bahwa penegakan hukum itu tidak boleh menyimpang : fiat justitia et pereat mundus (meskipun dunia runtuh, hukum harus ditegakkan). Dikaitkan dengan adanya perlindungan hukum terhadap suatu produk yang mengindikasikan geografis suatu daerah tentunya memberikan suatu nilai lebih dalam proses pemasaran kepada masyarakat. Tujuan perlindungan hukum untuk melindungi dan menjaga kelestarian. Selain itu, Indikasi Geografis juga sangat potensial untuk menjamin agar keuntungan ekonomi tertinggi dari suatu produk dapat tetap paling dinikmati oleh produsen dari daerah asal produk itu sendiri. Perlindungan hukum yang diperoleh memberikan suatu langkah yang pasti dalam memperdagangkan atau memproduksi produk tersebut. Tanpa adanya perlindungan hukum tentunya akan menjadi suatu perpecahan ketika produk tersebut mulai diperkenalkan ke pasar, dimana akan memungkin terjadi suatu pengalihan hak yang dilakukan oleh orang-orang berkepentingan namun tidak mempunyai hak untuk memasarkan produk tersebut atas dasar keuntungan yang diperoleh dalam pasar.

Peraturan mengenai Indikasi Geografis telah mengalami perubahan yang sebelumnya diatur secara sumir dalam Undang Undang Republik Indonesia Nomor 15 Tahun 2001 Tentang Merek sekarang telah diatur secara eksplisit di dalam Undang Undang Republik Indonesia Nomor 20 Tahun 2016 tentang Merek dan Indikasi Geografis. Berdasarkan Undang Undang Nomor 20 Tahun 2016 tentang Merek dan Indikasi Geografis dalam Pasal 1 angka 6 bahwa :

"Indikasi Geografis adalah suatu tanda yang menunjukkan daerah asal suatu barang dan/atau produk yang karena faktor lingkungan geografis termasuk faktor alarn, faktor manusia atau kornbinasi dari kedua faktor tersebut memberikan reputasi, kualitas, dan karakteristik tertentu pada barang dan/atau produk yang dihasilkan."

Pentingnya hukum atas Hak Kekayaan Intelektual barang atas hasil bumi yang khas tersebut dapat diberi perlindungan berdasarkan Indikasi Geografis dimohonkan serta dilakukan pendaftaran Indikasi Geografisnya untuk memperoleh sertifikat dalam rangka mengharapkan adanya perlindungan hukum. Berdasarkan data dan informasi dari layanan elektronik Direktorat Jenderal Kekayaan Intelektual sampai tahun 2017, bahwa komoditas pertanian yang sudah mendapatkan sertifikasi indikasi geografis yaitu berjumlah 40 komoditas. Jumlah komoditas terdaftar tersebut menjadi acuan untuk mendorong dilakukannya pendaftaran terhadap produk Indikasi Geografis.

Salah satu produk potensi Indikasi Geografis berasal dari Kabupaten Toba Samosir yaitu Andaliman (Merica Batak). Kabupaten Toba Samosir diresmikan pada tanggal 9 maret 1999. Andaliman (Merica Batak) merupakan tanaman yang khas dan bermanfaat besar khususnya bagi masakan suku batak di Kabupaten Toba Samosir. Andaliman yang dikenal sebagai Merica Batak berasal dari kulit luar buah beberapa jenis tumbuhan anggota marga Zanthoxylum Acanthopodium DC (suku jeruk-jerukan, rutaceae). Kekhususan karateristik produk Indikasi Geografis di Kabupaten Toba Samosir tersebut dihasilkan dari pengaruh kondisi alam setempat dan interaksinya dengan masyarakat sekitarnya. Kabupaten Toba Samosir merupakan daerah yang menjadi pusat tanaman yang menghasilkan Andaliman (Merica Batak), namun Andaliman (Merica Batak) belum didaftarkan sebagai Indikasi Geografis di Direktorat Jenderal Kekayaan Intelektual. Dari sisi itu lah dapat kita lihat bahwa terdapat kekosongan hukum di bidang Hak Kekayaan Intelektual khususnya dalam hal pengaturan kekayaan produk daerah tersebut khususnya untuk Andaliman (Merica Batak) sebagai produk Indikasi Geografis di Kabupaten Toba Samosir. 
Di Indonesia, produk yang memiliki kekhasan berpotensi sebagai produk Indikasi Geografis di suatu daerah, harus didaftarkan terlebih dahulu agar memperoleh perlindungan hukum demi mencapai kepastian hukum atas tanda kepemilikan produk daerah. Sisi positif yang diharapkan dari pendaftaran yaitu agar suatu saat ketika terjadi sengketa terkait dengan ambil alih hak atas produk Indikasi Geografis sangat membantu dalam pembuktian. Mengenai produk Indikasi Geografis dalam peraturan sekarang ini mempunyai pengaturan tersendiri yang artinya bahwa Indikasi Geografis sudah mendapatkan perhatian yang lebih. Sangat disayangkan apabila kita selalu berkutat dengan permasalahan seperti salah satu contoh menghadapi sengketa yang diakibatkan karena perebutan hak milik, hak menguasai dan lainnya.

Berdasarkan latar belakang tersebut, maka dapat ditentukan permasalahan sebagai berikut : (1) Unsur-unsur apa yang dapat dijadikan sebagai dasar dalam perolehan perlindungan hukum terhadap Andaliman (Merica Batak) sebagai Indikasi Geografis di Kabupaten Toba Samosir? (2) Upaya apa yang dapat dilakukan oleh pemerintah Kabupaten Toba Samosir untuk mewujudkan perlindungan hukum terhadap Andaliman (Merica Batak) sebagai Indikasi Geografis di Kabupaten Toba Samosir?

\section{Metode Penelitian}

Penelitian ini, menggunakan jenis penelitian hukum empiris yang menggunakan data primer sebagai data utama dengan melakukan penggalian data secara langsung dari sumbernya. Penelitian ini juga didukung dengan jenis penelitian normatif dengan cara meneliti bahan pustaka dengan mempelajari dan menelaah teori-teori, konsep-konsep serta peraturan yang berkaitan dengan permasalahan. Data primer diperoleh dengan melakukan wawancara langsung kepada pemerintahan Kabupaten Toba Samosir dengan Lokasi dalam penelitian ini dilakukan di Kabupaten Toba Samosir, Provinsi Sumatera Utara serta wawancara dengan masyarakat di Desa Borbor, Balige dan Silaen.

\section{B. Pembahasan}

1. Letak Geografis Tanaman Andaliman

Berdasarkan penelitian melalui wawancara langsung dengan Bapak Benny Diktus Sidabutar selaku Staf Dinas Pertanian (tanggal 30 Maret 2017 pukul 13.00 WIB), Andaliman tidak tumbuh dan tidak dibudidayakan menyebar di semua lokasi Kabupaten Toba Samosir tetapi hanya berpusat di daerah Borbor dan Silaen, Kabupaten Toba Samosir. Hampir 90 persen penduduk Desa Borbor, Balige dan Silaen menanam Andaliman. Letak pusat tanaman Andaliman dapat diperhatikan dalam gambar peta Kabupaten Toba Samosir.

\section{Gambar 1.}

Peta Lokasi Kabupaten Toba Samosir

(Wilayah penghasil Andaliman (Merica

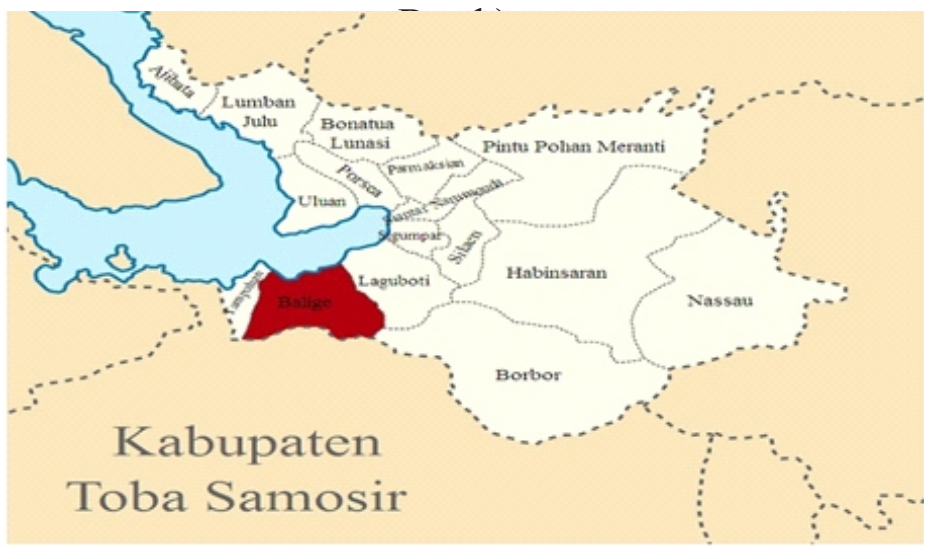

Sumber : Dinas Pertanian Kabupaten Toba Samosir (2017)

Andaliman juga tumbuh di daerah lain sekitar Borbor dan Silaen, namun tidak menunjukkan kualitas yang sama. Misalnya, di Porsea dan Habinsaran buah Andaliman yang dihasilkan kurang berbuah lebat dan memiliki rasa yang kurang getir dilidah. Bagian peta lokasi ini juga menjadi satu hal yang harus dicantumkan dalam Buku Persyaratan Indikasi Geografis.

Kabupaten Toba Samosir berada pada $2^{\circ} 03^{\prime}$ - $2^{\circ} 40^{\prime}$ Lintang Utara dan 98 $56^{\prime}$ $99^{\circ} 40^{\prime}$ Bujur Timur. Kabupaten Toba Samosir terletak pada wilayah dataran tinggi dengan ketinggian antara $900-2.200$ meter diatas 
permukaan laut. (Sumber : Data Pemerintah Kabupaten Toba Samosir Dinas Pertanian dan Perikanan, 2017). Berdasarkan uraian singkat mengenai letak astronomis diatas, maka dapat dikaji bahwa Andaliman sendiri dapat tumbuh pada daerah berketinggian 1.500 meter diatas permukaan laut, sehingga ketinggian daerah Kabupaten Toba Samosir memang merupakan salah satu faktor yang mendukung serta mempengaruhi pertumbuhan tanaman Andaliman.

Komposisi tanah didominasi jenis tanah Tufo Toba, pasir tercampur tanah liat, kapur dan sebagian lainnya berupa lapisan tanah batuan yang relatif kurang subur untuk pertanian. Kontur tanah yang beraneka ragam, yaitu datar, landai, miring dan terjal. Struktur tanahnya labil dan terletak pada wilayah gempa tektonik dan vulkanik. (Sumber : Hasil wawancara langsung kepada Bapak John Hover Siagian, tanggal 10 April 2017 pukul 13.00 WIB). Berdasarkan kajian singkat mengenai topografi Kabupaten Toba Samosir maka dapat dianalisis bahwa faktor ini menjadi satu keunikan, justru Andaliman banyak dan tumbuh subur di tanah kering berbeda dengan tanaman lainnya yang justru membutuhkan struktur tanah yang tidak kering dan subur.

Namun demikian, sekalipun Andaliman justru banyak tumbuh subur di tanah kering, tetap saja membutuhkan asupan air yang banyak hanya jenis tanahnya yang kering. Kabupaten Toba Samosir terletak pada garis khatulistiwa, dan tergolong pada iklim tropis basah dengan suhu berkisar antara $17^{\circ} \mathrm{C}-29^{\circ}$ $\mathrm{C}$ dan rata-rata kelembaban udara $85.04 \%$. Rata-rata tinggi curah hujan setiap tahun sebesar $223 \mathrm{~mm}$ dengan jumlah hari hujan sebanyak 17 hari. Curah hujan tertinggi terjadi pada bulan Desember dengan $759 \mathrm{~mm}$ dengan jumlah hari hujan sebanyak 15 hari. (Sumber: Data Pemerintahan Kabupaten Toba Samosir Dinas Pertanian dan Perikanan).

Berdasarkan data di atas, dapat dianalisis bahwa tanaman Andaliman dapat tumbuh subur di daerah dingin seperti daerah Kabupaten Toba Samosir. Curah hujan juga menjadi salah satu faktor yang sangat membantu dalam memberikan asupan air terhadap tanaman Andaliman. Tanpa curah hujan yang tinggi saja kawasan Kabupaten Toba Samosir sudah bersuhu lembab dan dingin apalagi kalau curah hujan tinggi maka semakin membantu kelembapan daerah tersebut.

\section{Manfaat Andaliman (Merica Batak)}

Andaliman adalah buah tanaman yang dijadikan bumbu masak khas Asia yang berasal dari kulit luar buah jenis tumbuhan anggota marga Zanthoxylum (suku jerukjerukan, Rutaceae) yang asalnya berpusat di Kabupaten Toba Samosir. Andaliman ini di Indonesia hanya dikenal sebagai bumbu untuk masakan Batak, sehingga dikenal orang luar daerah ini sebagai "merica batak". Masakan khas Batak seperti yang dinamakan arsik, tanggo-tanggo, manuk napinadar dan saksang memerlukan Andaliman (Merica Batak) sebagai bumbu yang tak tergantikan atau bisa disebut juga sebagai bumbu utama.

Andaliman memiliki aroma jeruk yang lembut namun "menggigit" serta getir di lidah sehingga menimbulkan sensasi kelu atau mati rasa di lidah, meskipun tidak sepedas cabai atau lada. Rasa kelu di lidah ini disebabkan adanya kandungan hydroxy-alpha-sanshool pada rempah Andaliman (Merica Batak) ini. Reaksi kelu yang muncul dilidah sangat khas membuat penikmat Andaliman itu sendiri merasa nagih untuk mencicipinya berulang ulang. Pohon Andaliman berupa perdu yang cukup rimbun. Batang pohonnya penuh duri runcing berwarna marun. Ujung batang runcing ini menyembunyikan pucuk-pucuk muda buah Andaliman. Buahnya sendiri tumbuh dari batang. Andaliman sangat mirip dengan lada. Kemiripannya itulah yang jadi alasan kenapa Andaliman kerap disebut sebagai merica batak ([http:// atemalem.com/andaliman-rempah-rahasiakhas-sumatera/] diunduh pada Januari 2016).

Andaliman menjadi salah satu tanaman dari empat tanaman endemik di Kabupaten Toba Samosir yang diusulkan memiliki perlindungan geografis, yaitu diharapkan adanya perlindungan dari aspek Indikasi Geografis ([http://harianandalas.com/kanalsumatera-utara/empat-tanaman-endemik- 
diusulkan-miliki-perlindungan-geografis] diunduh pada Januari 2016). Menariknya lagi, anak-anak kuliah dari sumatera yang merantau ke Jawa khususnya Yogyakarta sering menjadikan Andaliman menjadi salah satu oleh-oleh berharga atau bekal berharga untuk dibawa ke Yogyakarta. Andaliman tidak hanya bermanfaat sebagai Penyedap Makanan pada masakan khas suku Batak, tetapi Andaliman juga bisa dipergunakan sebagai Obat Herbal karena di dalam Andaliman mengandung Senyawa Aromatik dan Minyak Eksensial yang sangat bermanfaat untuk Kesehatan. Minyak Eksensial sendiri bermanfaat untuk mengurangi rasa sakit sekaligus menyembuhkan ketika tertusuk duri tanaman.

Tanaman Andaliman memasuki masa panen di usia tanam 1.5 tahun. Jika tidak terganggu oleh cuaca, satu batang andaliman bisa menghasilkan 5-7 Kg. Masa hidup tumbuhan ini bisa mencapai 10-15 tahun, cukup lama untuk sebuah tumbuhan yang menghasilkan keuntungan. (Sumber: hasil wawancara langsung kepada Responden Bapak B. Siregar pada tanggal 4 April 2017, sebagai salah satu warga pemilik usaha bibit tanaman Andaliman serta Penyuplai buah Andaliman).

\section{Unsur-unsur yang dijadikan sebagai dasar perolehan perlindungan hukum terhadap Andaliman (Merica Batak) sebagai Indikasi Geografis di Kabupaten Toba Samosir}

Undang Undang Nomor 20 Tahun 2016 tentang Merek dan Indikasi Geografis menjelaskan pengertian dari Indikasi Geografis dalam Pasal 1 Angka 6 bahwa Indikasi Geografis adalah:

"suatu tanda yang menunjukkan daerah asal suatu barang dan/atau produk yang karena faktor lingkungan geografis termasuk faktor alam, faktor manusia atau kombinasi dari kedua faktor tersebut memberikan reputasi, kualitas, dan karakteristik tertentu pada barang dan/atau produk yang dihasilkan."

Pengertian mengenai Indikasi Geografis yang tertuang didalam undang-undang tersebut secara tidak langsung menjelaskan bahwa ada unsur-unsur yang harus terkandung pada sebuah produk potensi Indikasi Geografis, yakni:

a. Tanda daerah asal suatu barang dan/atau produk

b. Produk ada dan berkembang karena faktor lingkungan geografis termasuk faktor alam

c. Produk ada dan berkembang karena faktor manusia

d. Menjadi produk yang memiliki reputasi, kualitas, dan karateristik yang khas.

Apabila memenuhi unsur-unsur produk potensi Indikasi Geografis, maka harus didaftarkan untuk menjadi produk Indikasi Geografis. Dalam hal pendaftaran harus memenuhi syarat sebagaimana yang dimaksud dalam Undang Undang Nomor 20 Tahun 2016 tentang Merek dan Indikasi Geografis pada Pasal 56 Ayat (1) dan (2) yakni

(1) Permohonan Indikasi Geografis tidak dapat didaftar jika:

a. bertentangan dengan ideologi negara, peraturan perundang-undangan, moralitas, agama, kesusilaan, dan ketertiban umum;

b. menyesatkan atau memperdaya masyarakat mengenai reputasi, kualitas, karakteristik, asal

c. sumber, proses pembuatan barang, dan/atau kegunaannya; dan

d. merupakan nama yang telah digunakan sebagai varietas tanaman dan digunakan bagi varietas tanaman yang sejenis, kecuali ada penambahan padanan kata yang menunjukkan faktor indikasi geografis yang sejenis.

(2) Permohonan Indikasi Geografis ditolakjika:

a. Dokumen Deskripsi Indikasi Geografis tidak dapat dibuktikan kebenarannya; dan/atau

b. memiliki persamaan pada keseluruhannya dengan Indikasi Geografis yang sudah terdaftar.

Berdasarkan pasal tersebut dijelaskan bahwa produk Indikasi Geografis harus memiliki sifat yang unik, nyata keberadaannya dan harus memiliki perbedaan 
dengan produk Indikasi Geografis yang telah terdaftar sekalipun merupakan produk yang sejenis.

Hal yang sama juga secara langsung menyebut unsur-unsur dan lebih rinci diatur di dalam Buku Indikasi Geografis Indonesia yang dikeluarkan oleh Direktorat Jenderal Kekayaan Intelektual. Buku Indikasi Geografis Indonesia menjelaskan bahwa sebuah produk berhasil dikatakan sebagai produk Indikasi Geografis apabila memenuhi syarat keberhasilan Indikasi Geografis yang dijadikan unsur-unsur yang ada pada produk potensi Indikasi Geografis. Unsur-unsur tersebut meskipun tidak secara langsung menyebutkan reputasi, kualitas dan karateristik tetapi sudah mencakup penjelasan unsur-unsur yang ada pada pengertian Indikasi Geografis pada Undang Undang Nomor 20 Tahun 2016 tentang Merek dan Indikasi Geografis sebagaimana yang telah diuraikan diatas. Adapun unsur-unsur tersebut adalah bahwa sebuah produk Indikasi Geografis harus dihadapkan dengan:

a. Sistem manajemen yang kuat dan efektif

b. Kualitas produk yang prima dan terjaga konsistensinya

c. Sistem pemasaran termasuk promosi yang kuat

d. Mampu memasok kebutuhan pasar dalam jumlah cukup secara berkelanjutan

e. Kemauan menegakkan ketentuan hukum terkait Indikasi Geografis

Berdasarkan hasil wawancara dengan Bapak Sahat M. Manullang selaku Sekretaris Dinas Pertanian dan Perikanan di Kabupaten Toba Samosir (tanggal 30 Maret 2017 pukul 14.23 WIB), dijelaskan bahwa Andaliman layak memperoleh perlindungan Indikasi Geografis. Adapun unsur-unsur tersebut adalah dianalisis dengan pendekatan perundang-undangan yaitu dengan memperhatikan nilai-nilai yang di konkretkan pada pengaturan Indikasi Geografis. Analisis dilakukan dengan menyandingkan syarat keberhasilan Indikasi Geografis sebagaimana yang tertulis pada pengaturan Indikasi Geografis dengan data yang diperoleh sebagai hasil penelitian. Adapun unsur-unsur tersebut yaitu sebagai berikut:

a. Sistem manajemen yang kuat dan efektif

Bapak Sahat M. Manullang mengucapkan bahwa Harga jual Andaliman sangat dipengaruhi oleh penyuplai ataupun produsen. "Pada saat produksi menghasilkan barang yang melimpah harga jual mencapai $\mathrm{Rp}$. $200.000,-/ K g$. Namun bila produksi sedang sedikit/langka harga jual mencapai Rp. 400.000,-/Kg tetapi tetap laku keras karena merupakan bumbu utama pada masakan khas batak" ujar Beliau. Hal yang sama juga disebutkan oleh Bapak B. Siregar sebagai responden yang berada di Desa Balige.

Apabila dianalisis hal ini menandakan bahwa dalam penjualan Andaliman sistem manajemen yang berjalan adalah sistem manajemen yang kuat dan efektif tetap melekat sekalipun harga Andaliman sedang menjulang tinggi.

b. Kualitas produk yang prima dan terjaga konsistensinya dengan baik

Andaliman memiliki 3 (tiga) fase ketika sudah dipanen. Andaliman yang segar atau masih muda berwarna hijau. Andaliman yang sudah matang berwarna merah. Semakin lama andaliman ketika kering menjadi berwarna hitam, uniknya rasanya tidak akan berubah dan tetap laku bahkan diluar bantuan mesin pendingin.

Berbeda jelas dengan tanaman dan/atau produk lainnya. Umumnya semua tanaman dan/atau produk semakin lama semakin tidak enak bahkan sering dikatakan sudah busuk dan tidak layak lagi di konsumsi. Hal ini yang menjadi karateristik Andaliman yang paling unik, hal ini menujukkan kualitas Andaliman yang sangat tinggi sekalipun penampilan buah Andaliman telah berubah tetapi rasa tetap sama.

Untuk lebih memperkuat data dapat ditunjukkan oleh gambar 2 berikut. 
Gambar 2. Andaliman dalam keadaan segar

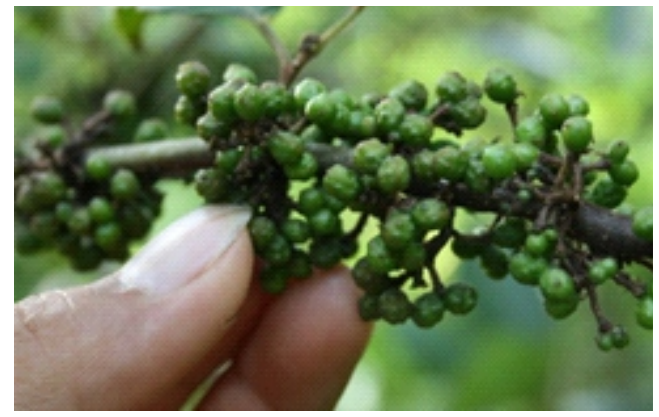

Sumber : Dokumen Pemerintahan Kabupaten Toba Samosir, 2017.

Gambar 3.

Andaliman (Merica Batak) dalam keadaan

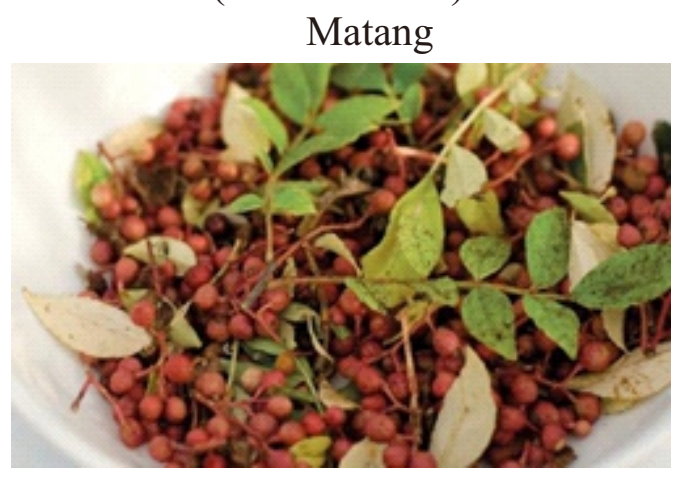

Sumber : Dokumen Pemerintahan Kabupaten Toba Samosir, 2017.

Gambar 4.

Andaliman (Merica Batak) ketika sudah kering berwarna hitam

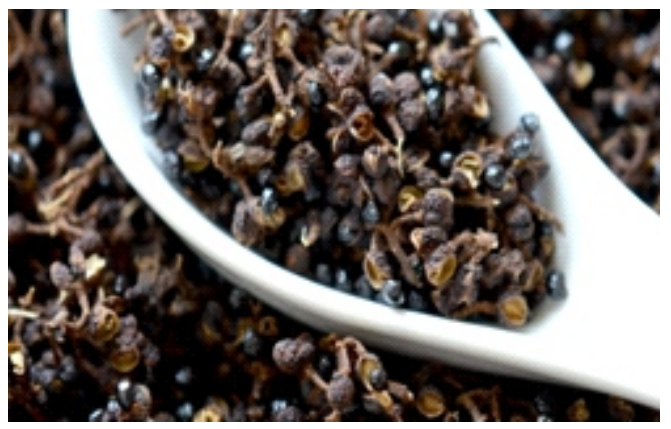

Sumber : Dokumen Pemerintahan Kabupaten Toba Samosir, 2017.

Apabila disandingkan dengan syarat keberhasilan produk Indikasi Geografis, hal ini menandakan bahwa Kualitas Andaliman merupakan kualitas produk yang prima dan terjaga konsistensinya dengan baik terutama konsistensinya dari segi rasa. Selain berdasarkan penjelasan narasumber, bahwa keunikan Andaliman dalam hal ini pun dialami penulis sendiri secara langsung. Selain telah memenuhi syarat keberhasilan produk Indikasi Geografis, uraian mengenai kualitas produk yang prima dan terjaga konsistensinya sebagai hasil penelitian juga dipakai untuk pemenuhan dokumentasi dalam Buku Persyaratan Indikasi Geografis, yakni dicantumkan pada bagian uraian mengenai metode yang digunakan untuk menguji kualitas barang yang dihasilkan.

c. Sistem pemasaran termasuk promosi yang kuat

Sistem pemasaran Andaliman yaitu secara Tradisional, namun kemana pun orang yang membutuhkan Andaliman khususnya suku batak pergi atau menetap sekalipun diluar Sumatera Utara hebatnya Andaliman tetap dicari untuk bumbu masak. Bahkan untuk rumah makan khas Batak yang buka di Yogya membutuhkan Andaliman sebagai bumbu masakan dagangannya. Karena itu Beliau menjelaskan diluar Kabupaten Toba Samosir telah diusahakan juga pemasaran Andaliman tetapi tetap dikawasan pasar tradisional yaitu di Pasar Inpres Senen dan Pasar Mayestik di Kebayoran Baru, Jakarta Selatan dan itupun tidak meyebar hanya ada satu atau dua kios yang menjual tetapi banyak yang mengetahui meskipun tidak menyebar.

Pengelolaan Andaliman masih tradisional digunakan sebagai bumbu kuliner di Kabupaten Toba Samosir. Sangat membanggakan kawasan Toba Samosir bahwa terakhir kali Andaliman dikembangkan untuk bumbu produk lain seperti Pizza Batak dan juga sudah mulai diolah sebagai bentuk bubuk. Berbicara Andaliman dalam Pizza sangat menarik. Percobaan dilakukan oleh seorang penduduk di Kabupaten Toba Samosir bernama Sebastian. Sekarang, bukan sekedar percobaan lagi tetapi sudah teruji enak sampai akhirnya sudah dibuka Pizza Andaliman Cafe yang terletak di Balige, Kabupaten Toba Samosir dan berdasarkan informasi dari wawancara langsung juga dinyatakan bahwa 
Cafe Andaliman Pizza tersebut mendapat untung besar biasanya sehari sampai titik juta rupiah, padahal sebelumnya cafe tersebut sepi saja sebelum menjadi Cafe Andaliman Pizza. Hal ini sungguh menarik dikarenakan Andaliman. (Sumber : Hasil wawancara langsung kepada Bapak B. Siregar pada tanggal 10 April 2017 pukul 15.00 WIB).

Apabila dianalisis hal ini menandakan bahwa sistem pemasarannya baik sekalipun masih di taraf tradisional dan promosinya kuat dibuktikan dengan banyak orang yang mengetahui tempat jual Andaliman di Jakarta meski tidak menyebar di banyak kios.

d. Mampu memasok kebutuhan pasar dalam jumlah cukup secara berkelanjutan

Andaliman berproduksi secara berkelanjutan dan masa hidup satu pohon tanaman Andaliman ini adalah 10-15 tahun. Hal ini menandakan bahwa Andaliman mampu memasok kebutuhan pasar dalam jumlah cukup seacara berkelanjutan, meskipun dalam waktu tertentu yang mungkin sangat jarang Andaliman sangat susah diperoleh, akan tetapi sekalipun tiba saatnya Andaliman sedang langka dan akhirnya mempengaruhi harga melambung tinggi tetapi tetap laku dan tetap dicari orang.

e. Kemauan menegakkan ketentuan hukum terkait Indikasi Geografis

Kemauan menegakkan ketentuan hukum terkait Indikasi Geografis juga merupakan salah satu syarat keberhasilan sebuah produk/barang dapat berhasil dikatakan produk Indikasi Geografis, justru hal ini lah menjadi salah satu maksud dalam penelitian ini. Setelah melakukan penelitian ternyata keuntungan yang diperoleh oleh peneliti sekaligus penulis adalah bahwa berhasil mendorong sekaligus mendorong semangat Pemerintah Kabupaten Toba Samosir untuk memajukan daerahnya salah satunya dengan peduli terhadap aset negara. Dalam hal ini setelah melakukan wawancara ke beberapa pejabat di Kantor Pemerintahan Kabupaten Toba Samosir, penulis menyimpulkan bahwa Pemerintah Kabupaten Toba Samosir punya kemauan dan keinginan yang kuat untuk mewujudkan perlindungan
Indikasi Geografis terhadap Andaliman sebagai Merica Batak.

Dari uraian secara rinci mengenai unsurunsur yang ada pada Andaliman sebagai syarat keberhasilan produk Indikasi Geografis dapat disimpulkan bahwa Andaliman berhasil dikatakan sebagai produk Indikasi Geografis karena memenuhi syarat keberhasilan produk Indikasi Geografis yang dijadikan unsur-unsur yang terkandung pada Andaliman sebagaimana yang telah diatur didalam pengaturan Indikasi Geografis. Bagian bahasan ini lah membuktikan bahwa Andaliman memenuhi syarat Objektif. Hal tersebut dapat lebih mendorong masayarakat Kabupaten Toba Samosir menyadari bahwa Andaliman memang sangat layak untuk mendapatkan perlindungan hukum dari segi Indikasi Geografis.

Unsur-unsur yang dijadikan sebagai dasar perolehan perlindungan hukum terhadap Andaliman (Merica Batak) yang telah diuraikan sebagai hasil penelitian juga berhasil dijadikan dokumentasi demi pemenuhan dokumen Buku Persyaratan Indikasi Geografis. Dokumentasi tersebut dicantumkan dalam Buku Persyaratan Indikasi Geografis demi pemenuhan salah satu syarat yang harus dicantumkan yakni pada bagian uraian mengenai karateristik dan kualitas yang membedakan barang yang bersangkutan dengan barang lain yang memiliki kategori sama, dan menjelaskan tentang hubungannya dengan daerah asal barang tersebut.

4. Analisis mengenai Upaya yang dapat dilakukan oleh Pemerintah Kabupaten Toba Samosir dalam mewujudkan perlindungan hukum terhadap Andaliman (Merica Batak)

Mengingat produk Indikasi Geografis merupakan salah satu kekayaan intelektual, diperlukan perlindungan kekayaan intelektual demi mencapai dorongan pertumbuhan ekonomi nasional serta menciptakan iklim yang sehat terhadap pertumbuhan dan perkembangan hak kekayaan intelektual lokal yang dapat bersaing dengan hak kekayaan intelektual asing. Perlindungan terhadap berbagai 
kekayaan intelektual yang tidak memadai bahkan tidak mempunyai kepastian hukum, dapat saja menimbulkan kekecewaan, juga malah dapat menghilangkan semangat berkarya bagi para petani ataupun pengolah produk Indikasi Geografis sebuah daerah. Hak kekayaan intelektual seperti produk sebagai Indikasi Geografis yang baru wajib diberikan perlindungan ketika produk tersebut mempunyai karakteristik dan keunikan dengan alasan diharapkan adanya pertimbangan keadilan, pemeliharaan produk daerah, pencegah perampasan oleh pihakpihak yang tidak berhak terhada produk indikasi geografis serta pengembangan penggunaan kepentingan hak milik daerah produk sebagai indikasi geografis.

Berdasarkan kajian singkat mengenai perlindungan hukum, penulis berpendapat bahwa dalam pembahasan ini lebih mengarah kepada perlindungan preventif yang bertujuan untuk mencegah terjadinya sengketa, sehingga sebuah ketentuan hukum ataupun peraturan baru yang dihadirkan sebagai upaya pencegahan atas tindakan pelanggaran hukum dan dapat diaplikasikan dengan membentuk dan/atau membuat suatu aturan hukum yang bersifat normatif. Penulisan ini dilakukan dengan menggunakan pendekatan perundangundangan. Setiap aturan yang dilaksanakan pasti ada yang melandasi atau disebut dengan dasar hukum yang telah teruji. Disini lah alasan menggunakan pendekatan perundangundangan adalah bahwa penelitian ini tidak lepas dari Undang Undang Nomor 20 Tahun 2016 tentang Merek dan Indikasi Geografis serta Buku Indikasi Geografis Indonesia yang diterbitkan langsung oleh Direktorat Jenderal Kekayaan Intelektual, yang dimana dengan metode pendekatan perundang-undangan ini peneliti perlu memahami hierarki dan asasasas dalam peraturan perundang undangan yang telah ada. Tujuan memahami undangundang yang telah ada sebelumnya adalah untuk menjadi acuan dalam upaya mendorong, merangsang serta mengajak masyarakat Kabupaten Toba Samosir melalui Pemerintah Kabupaten Toba Samosir untuk mengusahakan perolehan perlindungan
Indikasi Geografis terhadap tanaman Andaliman.

\section{Simpulan}

Berdasarkan hasil penelitian serta pembahasan yang telah dilakukan, maka dapat diambil kesimpulan sebagai berikut :

1. Secara objektif Andaliman (Merica Batak) memiliki karateristik yang khas dan memenuhi syarat sebagai produk Indikasi Geografis. Kekhasan tersebut sesuai dengan unsur-unsur dalam pengaturan syarat keberhasilan produk Indikasi Geografis. Andaliman memiliki karateristik yang khas ditunjukkan dengan fenomena yang terjadi pada pertumbuhan produk Andaliman.

2. Secara subjektif Pemerintah Kabupaten Toba Samosir memiliki legal standing untuk mewakili masyarakat dalam melakukan pendaftaran terhadap Andaliman (Merica Batak). Pemerintah Daerah Kabupaten Toba Samosir mempunyai kapasitas untuk memenuhi kepentingan masyarakat. Pemerintah Kabupaten Toba Samosir wajib menjalankan fungsi hukum yaitu mendaftarkan Andaliman agar memperoleh sertifikat dan dilindungi dari segi Indikasi Geografis.

Adapun saran yang diberikan adalah:

1. Hendaknya Pemerintah Kabupaten Toba Samosir, Dinas Pertanian, serta Dinas Perindustrian dan Perdagangan (Diskoperindag) Kabupaten Toba Samosir, perlu melakukan sosialisasi secara berkala mengenai Hak Kekayaan Intelektual kepada masyarakat pada umumnya khususnya pada para petani dan/atau pembudidaya tanaman Andaliman (Merica Batak). Sosialisasi dapat dilakukan dalam bentuk penyuluhan atau dapat juga berupa bentuk seminar khususnya mengenai Indikasi Geografis.

2. Bagi Petani juga pemerhati tanaman Endemik perlu dibentuk adanya 
asosiasi petani Andaliman (Merica Batak) sehingga kedepannya memudahkan dalam pengajuan permohonan pendaftaran Indikasi Geografis terkait pemenuhan dokumen dalam Buku Persyaratan Indikasi Geografis untuk setiap produk potensi Indikasi Geografis yang ada di daerahnya.

\section{DAFTAR PUSTAKA}

\section{Buku:}

Ahmad, Ramli. M. (2015). Indikasi Geografis Indonesia. Jakarta Selatan : Direktorat Jenderal Kekayaan Intelektual Kementrian Hukum Dan HAM RI

Ayu, Miranda Risang. ( 2006 ). Memperbincangkan Hak Kekayaan Intelektual Indikasi Geografis. Bandung: PT. Alumni

Mahfud, MD. (2014). Politik Hukum di Indonesia. Cetakan ke-6. Jakarta: Raja Grafindo Persada.

Marzuki, Peter Mahmud. (2005). Penelitian Hukum. Edisi Revisi. Jakarta: Kencana Prenadamedia Group.

Mertokusumo, Sudikno. (2010). Mengenal Hukum Suatu Pengantar. Edisi Revisi. Cetakan ke-05 Yogyakarta : Cahaya Atma Pustaka.

Sundari, E. \& Sumiarni, Endang. (2015). Politik Hukum \& Tata Hukum Indonesia. Yogyakarta : Cahaya Atma Putaka.

Sutedi, Adrian. (2009). Hak Atas Kekayaan Intelektual. Jakarta: Sinar Grafika.

Sunggono, Bambang. (2006). Metode Penelitian Hukum. Jakarta: Raja Grafindo Persada.

Suratman dan Philips Dillah. (2014). Metode Penenelitian Hukum. Bandung: Alfabeta.

Utomo, Tomi Suryo. (2010). Hak Kekayaan Intelektual (HKI) di Era Global. Yogyakarta: Graha Ilmu.

\section{Peraturan Perundang-Undangan:}

Undang-Undang Dasar Republik Indonesia Tahun 1945 Amandemen

Undang-Undang Republik Indonesia Nomor
15 Tahun 2001 Tentang Merek

Undang-Undang Republik Indonesia Nomor 20 Tahun 2016 Tentang Merek Dan Indikasi Geografis

\section{Website:}

http://atemalem.com/andaliman-rempahrahasia-khas-sumatera/, diunduh pada tanggal 25 Januari 2016 pukul 15.00 WIB.

http://harianandalas.com/kanal-sumaterautara/empat-tanaman-endemikdiusulkan-miliki-perlindungangeografis, diunduh pada tanggal 26 Januari 2016 pukul 21.00 WIB. 